\title{
Australian Ulama Response to Ash-Shabuny's View on Sexual Abuse against Women
}

\author{
Yuyun Affandi ${ }^{1}$, M. Al-Fatih Suryadilaga ${ }^{2}$, Musthofa Musthofa ${ }^{3}$ \\ Universitas Islam Negeri Walisongo Semarang, Indonesia ${ }^{1,3}$ \\ Universitas Islam Negeri Sunan Kalijaga Yogyakarta, Indonesia ${ }^{2}$ \\ \{yuyunaffandi@walisongo.ac.id ${ }^{1}$, muhammad alfatih suryadilaga@uin-suka.ac.id², \\ thofa@walisongo.ac.id ${ }^{3}$ \}
}

\begin{abstract}
Sexual Abuse against Women (SAAW) has increased, but existing norms have not been able to minimize it. There are differing perspectives between feminist thinking and intellectualist interpretation of the causes of SAAW. This study aims to determine the causes of SAAW in the Ash-Shabuny Tafsir and the Australian ulama's perceptions of its interpretation. This study combined library and field studies with thematic methods. The results showed that Ash-Shabuny's thinking about the causes of SAAW was different from the Textualist and Liberalist Mufassirin. Ash-Shabuny blamed both women and men in the case of SAAW. According to him, the causes of SAAW are: women do not cover their aurat; men and women do ikhtilath, and they both enter people's homes without permission. This view is shared by Fundamentalist Australian Ulama who tends to blame women. In contrast, according to the Australian Ulama Moderate and Liberal, SAAW is caused by the values in society and weak law enforcement.
\end{abstract}

Keywords: Response; Australian Ulama; Sexual Abuse; Mini Clothes; Ikhtilath; Entering People's Homes

\section{Introduction}

Even though Australia is a minority Muslim (2.2\% of the total population), apparently Australia has Ulama who can form harmony between religions, among them are M Tawhidi, Musa Cerantonio, and Ibrahim. Along with the increasing number of Sexual Harassment against Women (SAAW) cases, many countries make sexual harassment an important discourse. In Australia, the Catholic Church released 29 pastors who have been practicing SAAW to children, done since 1930s. Former star of the TV series called Hey Dad was sentenced to 10 years in prison for being convicted of committing SAAW to a child. It is not much different in Indonesia, such as Petis jarit Gilang UNAIR case; tragedy of UII alumnus; SAAW towards JIS students.[1] All of the sexual harassment that was experienced earlier has resulted in physical and mental damage.[2]

There are several assumptions that the SAAW issue is due to the theological understanding in which SAAW is a Qodrat and religion is accused as the driving force. Al-Qur'an contains the idea of equality, including women, not allowing violence. However, there is no sanction 
regarding SAAW in it. Even the classical interpretation considers SAAW to get the legality of the scriptures.

In this condition, to dismiss SAAW, it is time for al-Qur'an and its interpretation to become a demand. Religion is presented by God to uphold mercy. Al-Ghazali has formulated this idea, stating five principles for protecting human rights. Conceptually, the implementation is pursued through enforcing benefit or rejecting all violence. On this basis, all systems that legitimize the practice of harassment have to be eliminated. Many problems that did not arise at the time of the Prophet needed a solution. Thus, ijtihad has to be carried out. Through ijtihad, a paradigm shift is an alternative in forming new nuances in understanding AlQur'an,[3] such as the style of interpretation. The known features in interpretation are philosophical, scientific, and fiqh styles. Among the fiqh-styles, there is Rawai' al-bayan, an interpretation created by Ash-shabuny. The Mufassirs differ on the causes of SAAW. Some Ulama understands that the factors that influence it are the attitudes of women. This view is generally adherents of textual scripttrulation ( QS: al-ahzab:59). Meanwhile, according to other Mufassirs, SAAW is caused due to men's lack of faith. Feminists argue that inappropriate interpretation also contributes to making it easier for offenders to commit abuse. Because of various cultural backgrounds, the interpretation of the al-Qur'an has become the scapegoat for the various injustices that befall women.[4] The al-Qur'an has been presented for the liberation of all forms of injustice, including women. This view is shared by liberalcontextualists and feminists.

Works that discuss SAAW include "Sexual Harassment against Women at Work" which uses a feminist criminology perspective using participatory observation methods to feel what victims experience. A study also described a form of sexual harassment that occurs in the Municipal Police Office in Jakarta.[5] Furthermore, Iqbal's study on "Sexual Harassment Cases in Public Transportation According to the Decision of the Central Jakarta District Court" discussed that GBSM that occurs in public transportation in which the victims are not only normal women but also those with disabilities.[6] Then, there is a study entitled "Tafsir Empower Female Sexuality" which examined the theology of women's sexuality; "Analysis of Interpretation of Homosexual Verses and Illustrations of Homosexual Behavior of the time of the prophet Luth" There is also the discussion on "Sexual harassment in the view of Islamic law" by M Nur which explains that sexual harassment is a despicable act since these activities can only be done through marriage. Allah has also provided signs in order not to do this kind of behavior. Moreover, there is a work of Nur Rofiah on "Sexuality of the Sodomities in the Perspective of Al-Qur'an." It was a literature study using a qualitative method which shows that the Sodomities narrated in the al-Qur'an are not limited to homosexuals. The Sodomities have a bisexual orientation to their wives (heterosexual) and their fellow men (homosexual). The implication of the findings of this study might change the paradigm of society towards homosexuals based on the story of the Sodomities in the Al-Qur'an. From the above explanation, it can be inferred that the majority of SAAW's works are written in a general perspective and religious interpretation. Meanwhile, the study of Ash-Shabuny Tafsir and Australian Ulama Response specifically is not available yet. This paper is expected to complement the existing ones. It aims to determine the factors that influence SAAW according to Ash-Shabuny in Tafsir Rawai' al-Bayan as well as to look for answers about the perceptions of Australian Ulama on their interpretation. 


\section{Research Method}

This study was designed with a qualitative approach that focused more on the factors that influence SAAW according to Ash-Shabuny and the Australian Ulama's Perception of his interpretation as primary data. Meanwhile, the secondary data were under the object of the problem. Thus, this study was conducted in a combination of library research and field data. The researcher looked into documents, selected, and concluded from the available data. This study employed a thematic method with hermeneutical data analysis techniques which include the sociological approach used to analyze the social background of Ash-Shabuny's thought, the historical criticism approach used to analyze the history of the development of AshShabuny's thought in understanding SAAW, understanding intertextuality to explain the relationship between ash-Shabuny's work of interpretation and his other works, and understanding the hermeneutic circle. Then, the results of the literature review were tested in the field using observation and interviews. The conclusions were then drawn after all the data were obtained.

\section{Discussion}

Since 14 centuries ago, the Al-Qur'an (QS. Fatir: 35) has categorized Ulama into 3: 1Dzalim li nafsih, (ulamaussu'/evil to himself).2-Muqtashid (middle scholars ), and 3-sabiq bi al-Khayrat (race in goodness). The experts differed in defining Ulama. Among the classical Ulama, namely, Ibn Juraij wrote the opinion of "Atha. He considered Ulama as the on "who knows Allah is the one who is pious".[7, p. 49] In the first period, the Ulama were at the same time as umara. However, after the dynasty system became known, the categories of Ulama began to vary. Some dare to oppose the unjust Umara, some tolerate falsehood, and some are indifferent. In the classical period, the typology of Ulama was divided into two groups, religious scholars such as Tafsir, Hadith, and Kalam, and non-religious scholars such as philosophy, medicine, and mathematics.

In the modern era, the concept of Ulama has undergone a shift. Ulamas are not only those who are knowledgeable in religious knowledge but also those who are capable of taking part in the field of development.[8] Meanwhile, from the methodological aspect, the typology of Ulama is divided into several classifications, such as Typology of traditional thoughts, modernity thought, and neomodernity thought.[9] Seen from the aspect of the role and thought, the Ulama category is divided into three groups, Liberal, Moderate, and Fundamentalist Ulama. First, Liberal Ulamas are scholars who deconstruct texts, use the hermeneutic method of interpretation with the concept of depending on the realities of the times, where the implications of its hujjah application are on the sociological aspects. According to them, the most important thing is how the text can be connected to the context of Maqosid Sharia. Second, Fundamentalist Ulamas are those who carry out the purification of tawhid, salafi. Those who defend the basic teachings of Islam, keep away from all forms of superstition, bid'ah, and khurafat.[10] There are two principles of fundamentalism: first, it has a principle of resistance to all forms deemed harmful to religion. Second, they reject hermeneutics. They refuse a critical attitude towards the text and its interpretation. Third, moderate Ulamas have an intermediate attitude between excessive attitude towards religion and indifference. Theological representation of moderation is in the form of an attitude of avoiding extremity. A moderate attitude with its middle way makes the presence of Islam as a religion of rahmatan lil alamin. In short, they are Ulama who build a paradigm of social 
relations with the principle of dialogue between theological text and context. What passes in turats, while developing a constructive, dynamic, and balanced religious attitude to create an ideal society with the main ideas of welfare, yet tolerant, giving to minorities and the majority with a spirit of brotherhood, nationality, and respect for humanity. Since the Australian Ulama mentioned earlier have similarities with the Ulama typology categorization theory based on their roles and thoughts, moderate ulama, liberal ulama, and fundamentalist ulama, this typology was being tested in the field.

Sexual Harassment is generally defined as sexual harassment that can be committed against men or women. Yet, in reality, it is mostly done by men against women. Therefore, it is better known as gender-based sexual molestation.[11, p. 63] SAAW occurs due to differences in sociological backgrounds. Women always appear as figures that have problems with their bodies. Almost all ancient civilizations and major world religions have also legitimized this point of view. During the Middle Ages, the fate of women did not change. They are still experiencing various harassments. British legislation still recognizes the husband's right to sell his wife. The three religions (Judaism, Christianity, and Islam) believe that Eve or Hawwa was created from Adam's rib, although there is no single verse that contains the process of creating Eve.[12, p. 3] However, classical and modern interpretations described women as a source of lust that plunges men. In general, two factors influence Sexual Harassment (SH). The first one is an internal factor. People with a minimum level of sexual maturity, negative knowledge about reproductive health, tend for their sexual drive to be less recognized. The second one is the external factors. SH can be caused by a lack of communication between parents and children as well as promiscuity.[13, p. 143] National Commission on Human Rights reinforces the cause of external factors, that the police in Indonesia does not yet have the instruments to resolve the complexity of the SH from the legal system. There is little similarity to the second factor. Muhammad Helmi said that SH was caused by the government, community, family, and parents who failed to carry out their duties in protecting children's rights.[14] Meanwhile, according to feminists, SH happens due to the existence of superior and inferior gender classes.[4] It proves the existence of a power structure that is too favorable to men, permissive attitudes of violence and certain domination, as well as negligence of the SH case. The results of a study conducted at UNILA were different from the previous one for the victim was a domestic helper. The discussion shows that the factors that cause SAAW are: 1. social factors, the employer's home environment is quiet; economic factors, the dependence of the victim on the perpetrator; 3 . the educational factor, the victim's low education is utilized by the employer; 4. religious factors, the employer's insecure faith, and piety; 5. family factors, the employer's household condition that is not harmonious; 6. biological factors, male employers who have sex disorders; 7. psychological factors, the perpetrator's evil intentions; 8 . internal factors of the victim, having an attractive appearance. From several descriptions of the above discussion, it turns out that the factors that cause SAAW are not the same since the victims are different in terms of age, educational background, economic conditions, and psychological state. The perpetrator's condition is varied. Besides, the environment and conditions surrounding the perpetrator and victim are heterogeneous. Feminists are more likely to blame culture and interpretations in favor of Patriarchy. Meanwhile, some others blame women.

The results of this study showed that Ash-Shabuny is alleged to have textual-scriptural thinking since he wrote his work when he was still in Mecca. His work tended to blame women, which is not true. Ash-Shabuny's understanding of the causes of SAAW is as follows: The first factor that causes SAAW is due to the women do not cover their aurat (QS.al-ahzab: 59). According to him, women are required to cover all their bodies, including their faces. If 
they do not do so, it means that those women are expecting distraction for it can lead the men to lack faith aroused by their beauty and then commit sexual harassment. Especially, the historical context of the passage of this verse was during the time of ignorance. It will not be a matter if at night a woman leaves the house wearing a veil. Meanwhile, the second cause of SAAW refers to QS.an-Nur:30-31. According to Ash-Shabuny, this verse instructs Muslims to look away and look after their genitals in front of the opposite sex who is not a mahram since gaze is likened to a devil's arrow. When someone sees something that does not belong to him, the devil will whisper him to sin. Starting from sight or gaze, the time will process it into lust which is hard to control his biological emotions leading to a crime. Ash-Shabuny linked the previous verse with the issue of ikhtilath (association between men and women). He also quoted one of the writings of western women from an international journal that supported his opinion that women have to follow Arabic culture and not do ikhtilath like western countries. This verse is not only intended for men but also for women. As for the third case of SAAW aimed at men and women (QS annur: 27-28),[15, pp. 73, 147 and 150] which is entering someone else's house without permission. According to him, this is to keep a person's mind and should to be always clean from illegal lust. There is a possibility that the owner of the house is exposed to her aurat and does not want to be seen by anyone. If a guest enters without permission seeing the scene, there might be a dirty intention to sexually harass her.

In responding to ash-Shabuny's Tafsir or interpretation of SAAW, the responses of Australian Ulamas are mixed. Regarding the first SAAW factor, wearing non syar'iy attire is one of the causes of SAAW. Australian Ulama (Moderate Group) argues that even though Muslim clothing is required, it is not the cause of SAAW. SAAW is more likely caused by a society's value system and respect for values of gender equality. Apart from this view, some agree with this group but have different arguments, the Liberal group. They see that not wearing syar'iy is not the cause of SAAW since the law is only a recommendation and culture. SAAW is more likely caused by the quality of education and the quality of law enforcement. Meanwhile, the fundamentalist group has the same opinion as Ash-Shabuny that not wearing syar' clothes is the cause of SAAW. When the female body becomes public consumption, it causes the opposite sex to fantasize and cannot control lust.

Meanwhile, the views of Australian Ulama on the second cause, not holding their gaze and not protecting their genitals (ikhtilath), are also varied. According to the moderate group, promiscuity which is common in educational institutions as well as in the office cannot be said to be the cause of harassment since many women who are ikhtilath there do not experience sexual harassment. Harassment is more often caused by special ikhtilath, being together in a quiet place. Meanwhile, according to the Liberal group, the concept of ikhtilath in a social system that applies human rights might differ in rules. Each culture is not the same scope. The occurrence of sexual harassment is "relative." Promiscuity is not a factor in causing sexual harassment. As in Australia, ikhtilath is a human right. Women become safe, precisely for the government punished the perpetrators of harassment. In contrast, Fundamentalists believe that among the causes of sexual harassment experienced by women are due to ikhtilath, with promiscuity where a man free to look at women, to communicate with women, and to ask for dates causing men to abuse women.

The last factor of the causes of sexual harassment according to Ash-Shabuny is because men or women do not ask permission before entering someone else's house. Responding to this view, Australian ulama believes that this is not necessarily the cause of sexual harassment. The moderate group considers this only applies to people who are strangers. If the one who enters someone's house without permission is a close relative, it will not be a problem. Meanwhile, according to the Liberal group, entering someone else's house without permission 
is an act of violation of the law. In the context of the development of modern society, such as in Australia, this act is in a criminal area for it has harassed property, privacy, and comfort in the internal home. However, it cannot be said to be the cause of SAAW. The Fundamentalist group has a different opinion. They state that entering someone else's house is required to ask permission in advance. If the guests are not allowed to enter, even though they have close relationships, they are prohibited to enter. This is to anticipate that guests are not invited to witness a stimulating sight.

\section{Conclusion}

According to Ash-Shabuny, SAAW is not solely caused by women but a combination of men and women. There are three reasons for SAAW: (1) Women do not cover their aurat (QS: al-ahzab: 59). (2) Men and women do ikhtilath (QS: an-Nur: 30-31); (3) Men or women enter another's house without permission (Q.S. an-Nur: 27-28). His perspective was responded to by Australian Ulama differently. The view of Ash-Shabuny is fully followed/approved by the Australian Fundamentalist Ulama who emphasize mini-dress (not covering one's aurat / not syar'i) and entering the house without permission as the main causes of sexual harassment of women.

A different response emerged from moderate and liberal Australian Ulama. These groups argue that mini-dress (not syar'i) is not the cause of SAAW. This sexual harassment is more caused by values in society and weak law enforcement. Likewise, a view that ikhtilath is seen as the cause of SAAW. They argue that many men and women mingle (ikhtilath) but there is no SAAW. The concept of $i k h t i l a t h$ differs in social rules/ systems. Women become safe for the enforcement of punishment from the state. Likewise, Liberalist Ulama is of the view that entering someone else's house without permission is not the cause of SAAW but a criminal offense. In contrast to that, the Moderate Australian Ulama views entering a house without permission as the cause of SAAW if the perpetrator is unknown or strangers. If the perpetrator is a close relative, it is not part of the cause of SAAW. 


\section{References}

[1] "OC Kaligis: Pelaku baru paedofil JIS bukan orang Indonesia | merdeka.com.”.

[2] I. Noviana, "Kekerasan Seksual Terhadap Anak: Dampak dan Penanganannya," Sosio Inf., vol. 1, no. 1, Aug. 2015, doi: 10.33007/INF.V1I1.87.

[3] Y. Affandi, Pemberdayaan dan Pendampingan Perempuan Korban Kekerasan Seksual Perspektif al-Qur'an. Semarang: Walisongo Press, 2010.

[4] M. I. Fauzan, N. Sambas, and D. Andriasari, "Normative Juridical to Analyze and Observe Castrated Sanction Implementation for Sexual Violence Executor Toward Underage Child in Indonesia Based on Acts Number 17 Year 2016 and its Comparison in Australia," Int. Conf. ASEAN Community Dev., vol. 1, no. 1, Sep. 2017.

[5] F. Dwiyanti, "Pelecehan Seksual Pada Perempuan Di Tempat Kerja (Studi Kasus Kantor Satpol PP Provinsi DKI Jakarta),” J. Kriminologi Indones., vol. 10, no. 1, pp. 29-36, 2014.

[6] I. Ramdhani, "Kasus Pelecehan Seksual Dalam Transportasi Umum Menurut Putusan Pengadilan Negeri Jakarta Pusat," SALAM J. Sos. dan Budaya Syar-i, vol. 4, no. 1, pp. 95-120, May 2017, doi: 10.15408/sjsbs.v4i1.7871.

[7] N. I. Y. al-Qurtuby, Jami’ Bayan al-Ilm wa Faḍlihi. Beirut: Muassasah al-Risalah.

[8] Y. Yumna, "Ulama sebagai Waratsatul Anbiya: Pergeseran Nilai Ulama di Mata Masyarakat Aceh," Syifa al-Qulub, vol. 3, no. 1, pp. 18-30, Aug. 2018, doi: 10.15575/saq.v3i1.3141.

[9] M. Mutrofin, "Ulama Indonesia Kontemporer: Peran, Tipologi, dan Pemikiran," Din. Penelit. Media Komun. Penelit. Sos. Keagamaan, vol. 19, no. 1, pp. 105-124, Jul. 2019, doi: 10.21274/dinamika.2019.19.1.105-124.

[10] O. Setiadi, "Peta Pemikiran Politik Islam: Liberal, Moderat, dan Fundamental," Politea J. Pemikir. Polit. Islam, vol. 2, no. 1, p. 99, Jun. 2019, doi: 10.21043/politea.v2i1.5283.

[11] M. Sa'dan, "Reinterpretasi Teologi Kekerasan Seksual terhadap Perempuan: Kajian Tafsir Amina Wadud," J. Peremp. untuk pencerahan dan kesetaraan, vol. 21, no. 2, pp. 85-100, 2016.

[12] M. Nabilah Mohd Noor and M. Shafiee Hamzah, "Defamation by Women Mentioned in Surah Yusuf According to Hamka: A Review," Int. J. Acad. Res. Bus. Soc. Sci., vol. 7, no. 12, pp. 631-639, 2017, doi: 10.6007/IJARBSS/v7-i12/3645.

[13] B. J. Aditya, "Menjadi sintas: tindakan dan upaya pencegahan dan pemulihan kekerasan seksual," vol. 21, no. 2, pp. 47-64, 2016.

[14] K. K. Lewoleba and M. H. Fahrazi, "Studi Faktor-Faktor Terjadinya Tindak Kekerasan Seksual pada Anak-Anak," Esensi Huk., vol. 2, no. 1, pp. 27-48, Jul. 2020, doi: 10.35586/esensihukum.v2i1.20.

[15] M. A. Shabuni, Shafwah al-Tafâsîr, vol. 3. Kairo: Darus Shabuni, 2009. 